\title{
Looking Abroad for Growth: A Study of International Student's Symbolic Motivations in Attending South Korean Universities
}

\author{
Otabek Juraev ${ }^{1}$, Kiattipoom Kiatkawsin ${ }^{2, * \mathbb{D}}$, Iroda Mukhammadieva ${ }^{3}$ and Ji-Hern Kim $^{1}$ \\ 1 Department of Business Administration, Sejong University, Seoul 05006, Korea; ojuraev@gmail.com (O.J.); \\ jihern@sejong.ac.kr (J.-H.K.) \\ 2 Tourism Industry Data Analytics Lab (TIDAL), Department of Hospitality and Tourism Management, \\ Sejong University, Seoul 05006, Korea \\ 3 Department of Hospitality and Tourism Management, Sejong University, Seoul 05006, Korea; \\ irodastrong87@gmail.com \\ * Correspondence: kiatkawsin@gmail.com
}

check for

updates

Citation: Juraev, O.; Kiatkawsin, K.;

Mukhammadieva, I.; Kim, J.-H.

Looking Abroad for Growth: A Study

of International Student's Symbolic

Motivations in Attending South

Korean Universities. Sustainability

2022, 14, 213. https://doi.org/

$10.3390 /$ su14010213

Academic Editor: George

Gunnesch-Luca

Received: 26 November 2021

Accepted: 22 December 2021

Published: 26 December 2021

Publisher's Note: MDPI stays neutral with regard to jurisdictional claims in published maps and institutional affiliations.

Copyright: (C) 2021 by the authors. Licensee MDPI, Basel, Switzerland. This article is an open access article distributed under the terms and conditions of the Creative Commons Attribution (CC BY) license (https:// creativecommons.org/licenses/by/ $4.0 /)$.

\begin{abstract}
South Korean universities have been facing student shortages to sustain their growth due to its severe population decline. The Korean government has since introduced policies to attract more international students to the country. The present study examined the prestige-seeking tendencies of international students in Korea and their influence on students' satisfaction levels. The five dimensions of prestige-seeking behavior were adopted to help explain students' satisfaction levels. Research samples were current and former international students in Korea. The findings reveal the quality of the education did not contribute directly to the students' overall satisfaction level. Instead, it was hedonic elements that affected satisfaction. Moreover, status, snob, and bandwagon effects contributed significantly to the quality and hedonic motives.
\end{abstract}

Keywords: university development; international students; higher education; prestige consumption; student satisfaction; Korean education

\section{Introduction}

Pursuing higher education abroad has been an ever-growing trend in most parts of the world in the last few decades. In 2019, around 6 million students were studying outside of their own country [1]. Concurrently, universities and education systems at large looked into the international market for growth and to supplement other local industries. For example, South Korea strategically promotes its universities to attract foreign students to help fulfill the language needs in the international trade sector and to offset the declining population [2,3].

Typically, the availability of programs, superior quality of education, language learning opportunity, and the preference of foreign degrees among the local employers are key determinants of popular destinations for higher education [4-6]. Hence, English-speaking countries such as the UK, Australia, and the USA are among the top destinations for prospective students $[1,7,8]$. Although Korea does not possess some of the attributes typically considered desirable, such as being an English-speaking nation and having a global reputation for its higher education, the government still introduced policies to attract more international students from the early 2000s [9]. Consequently, international students' enrollment continues to climb. One report showed a significant increase from 49,270 students in 2004 to 153,695 in 2020 [10]. The Korean government targeted international students to account for $5 \%$ of the entire higher education enrollment by 2023. They mobilized funds for universities to expand English-track programs, easing visa requirements, and enhancing employment support to help achieve this target $[2,3,10]$.

The plethora of previous studies on students' motivation to study abroad has found many factors that were important in the decision-making process. The stated motives ranged from following friends to pressure from parents and from future career enhancement 
to lifestyle change [4,11-14]. The push-and-pull framework was often seen deployed to explore students' decisions to study abroad $[5,13]$. The push factors looked at what drives a student to leave their home country for higher education while the pull factors explained the destination and eventually institute of higher education to enroll [13]. The results are often dependent on the student's country of origin and the local higher education market. In China, a popular push factor was the overly fierce competitiveness of the college entrance exam [5]. At the same time, Vietnamese students reported the ability to acquire foreign language skills to be one of the leading reasons to study abroad [13].

One common approach by most previous studies was only focusing on anticipated benefits of studying abroad [15-17]. More specifically, the focus was placed on tangible benefits and rational planning such as opportunities to acquire new skills and experiences, long-term career prospects, and even migration opportunities $[18,19]$. One of the first barriers to studying abroad has always been the cost and value prospect $[16,20]$. While success is never guaranteed after studying abroad, many students that could afford it still choose to pay the premium [20-22]. When looking at studying abroad as a premium option in relation to studying at domestic institutions, there is still a lack of research that explores this perspective in-depth.

A premium price is traditionally associated with prestige products [23]. More recently, studies started to apply the concept of prestige to services as well [24-26]. A prestige product or service usually has the following characteristics. First, they offer comparatively higher quality products than most of the market [27]. Secondly, they can be harder to find and purchase by a smaller group of consumers [26]. Third, they tend to elicit novelty and exclusivity to those who consume them [28]. Lastly, they are usually priced considerably higher than their non-prestige counterpart [29]. These four characteristics are applicable to the studying abroad market. Therefore, it gives the opportunity to study the motivation to study abroad from a different perspective, namely from the symbolic representation of novelty and prestige.

Although empirical studies have found that prestige and status were often associated with international students' motivation and decisions $[4,11,12,16,20,22]$, no studies have taken the opportunities to comprehensively explore the multi-dimensionality of prestige consumption in the international higher education context. Hence, the following objectives were developed to help fulfill the research gap. First, this present research identified the five dimensions of prestige-consumption behaviors by Vigneron and Johnson (1999) as the most comprehensive framework to explain the motivations to consume prestige products $[26,30]$. Secondly, the study also looked to test the impact of prestige-consumption motivation on the students' level of satisfaction. Satisfaction has often been used as an indicator for service providers to gauge their quality against students' prior expectations [31-33]. Lastly, the study validated the study model in the Korean higher education context. Korea is not considered a traditional destination for higher education. Nevertheless, the government's ambition made Korea an interesting research context for the study because the findings may yield valuable insights for other countries and institutions for strategic planning.

\section{Literature Review}

\subsection{Prestige Seeking at Universities}

The notion of prestige has always been closely associated with universities. University rankings were first introduced back in the 1870s to give information about the universities and their scholars to government officials [34]. Since then, university ranking has become one of the most important influences for students and their parents in decision making [35]. The impact of ranking meant attending a highly ranked university may elevate one's social status among their peers $[20,36]$. The elevated status may often lead to favorable outcomes regarding employment and future opportunities [37]. Unsurprisingly, students generally tend to desire to be a part of the prestige group [38,39]. At the same time, prestigious institutions are expected to provide high-quality education to students and often produce highly skilled graduates [31,40]. Studying abroad was also found to help enhance cultural 
and interprofessional competencies that may be more difficult to find when studying domestically [41]. In sum, universities have always leveraged the level of perceived prestige as a method to appeal to students, faculty, staff, regulators, and investors [34,36,38,42]. However, a limited attempt has been made to investigate prestige seeking outside of the ranking context, particularly from a personal and social motivation perspective.

\subsection{Studying Abroad in Korea}

One of the most critical drivers of a studying abroad destination has been the English language. Specifically, countries that speak English natively tend to be among the most popular destinations [43]. Although Korea does not speak English natively, the country shares one key characteristic with the top destinations, that is, its economy. The leading countries are the United States of America, the United Kingdom, Australia, France, and Germany [44]. These destinations are among the world's leading economies. When it comes to destinations for studying abroad, the economic level contributes positively to the destination image that would attract international students [22,45-47]. A positive destination image for higher education includes a number of attributes, including perceived student benefits (such as employment opportunities, quality of life, and permit requirements) and tourism attractions (such as sightseeing opportunities, climates, and accessibility) in addition to the educational attributes (such as program selection, program quality, and educational environment) [31,46,48-53]. Although most of the attributes of Korea are comparable to other advanced economies, the underlying symbolic motivations among international students have never been previously explored.

\subsection{Prestige-Seeking Behavior}

Prestige products or services are chiefly characterized by scarcity $[24,30]$. Scarcity can be due to the rarity of the products in terms of supply or in terms of affordability when compared to the alternatives [28]. In other words, prestige products tend to be priced higher than the norm and consequently are being purchased less frequently [26]. Prestige products tend to offer superior quality than non-prestige products but are priced proportionately higher at the same time $[29,54]$. In the present study's context, for an Uzbek student attending a local university, it can be substantially more affordable than going abroad, especially to Korea, due to the generally higher living costs. Even though the underlying product functionalities of higher education are the same.

Prestige-seeking refers to the motivation that drives the purchase of products or consumption of services that are generally perceived to be higher in quality and tend to have a higher price associated with it $[29,55]$. The drivers to consume prestige products encompass a broad range of considerations. One of the most widely accepted frameworks that explain prestige-seeking motivation has been by Vigneron and Johnson (1999) [26,29]. They introduced the prestige-seeking consumer behavior framework that consists of five dimensions. These five dimensions are categorized into two types, publicly self-conscious (Veblen, snob, and bandwagon) and privately self-consciousness (hedonist and perfectionist). All given dimensions are conceptualized to drive any prestige consumption at the same time [29].

\subsubsection{Veblen Effect}

The first driver is termed the Veblen effect. The term is named after Thorstein Veblen, who introduced the concept of conspicuous consumption in his book The Theory of the Leisure Class in $1988[28,56]$. Conspicuous consumption refers to the notion that consumption behaviors can indicate people in different social classes [57]. At the same time, some people are motivated to consume products that ordinary people do not consume. Instead, only someone belonging to the higher social class would consume them [58]. It is also assumed those prestige products are often priced higher, and only wealthy people can afford them [59]. Studying abroad is not affordable for most people in Uzbekistan. Thus, the ability to go abroad and attend a university may be considered prestigious and grant the student a higher status than those who did not. 


\subsubsection{Snob Effect}

Prestige products can also be determined not only by price $[28,60]$. One may obtain the prestige status from distinguishing oneself from the common herd [61]. The snob effect explains consumers' drive to consume products that may elicit certain notions, such as being early adopters of technology or someone who is an expert in a particular type of product $[26,29]$. For example, a study found that people who frequent Michelin-starred restaurants are also driven to be considered the foodie in their inner circle and when their friends and family seek advice on dining out [26]. Therefore, students could be motivated to study abroad to stand out from the pool of other candidates in the job market.

The present study conceptualized the snob effect following the framework of consumers' need for uniqueness (CNFU) [62,63]. The CNFU posited that individuals have a varying degree of motivation to be unique [64]. The pursuits of being different or unique from the non-prestige group can be divided into three dimensions. The first is creative choice, which is how one would seek uniqueness from creating a different style for oneself that can be rare when compared to the rest [63]. The second dimension is unpopular choice. It refers to how an individual may choose to purchase or consume products that are considered unpopular among the general public [60,62]. Avoidance of similarity is the last dimension. This dimension refers to the loss of interest and eventually discontinuing usage of or patronizing products or services that have become commonplace [26]. In other words, as long as the chosen product or activity remains rare and unique, he or she is likely to continue.

\subsubsection{Bandwagon Effect}

The desire to join a selected group of people can also be another motivation to consume prestige products $[26,29]$. The bandwagon effect is the desire to earn prestige status by having commonalities with a reference group [29]. A reference group refers to a group of people who share a common attribute desired by an individual [55]. For example, successful people may have a common trait in that they have studied abroad. Consequently, students may feel if they also study abroad, they would be considered in the same echelon. Note that the snob effect and the bandwagon effect are present simultaneously [65]. While the snob effect drives an individual to distinguish themself from the common herd, the bandwagon effect drives that individual to follow the reference group [26,28].

The bandwagon effect in this present study was measured using the susceptibility to interpersonal influence scale (SUSCEP) [66,67]. The SUSCEP scale proposed that the bandwagon effect or the desire to conform to group norms can be split into two dimensions. The first is referred to as normative influence. It is the tendency to conform to the members expectations in the reference group [68]. On the other hand, informational influence tends to accept information from others as evidence about reality [69].

\subsubsection{Perfectionist Effect}

The first of the two private self-consciousness constructs is the perfectionist effect. Private self-consciousness constructs (also referred to as personal influence) differ from the public self-consciousness (also referred to as interpersonal influence) in that these motives are generated within oneself and the consumption attributes (such as superior quality and emotional benefits) are usually not publicly visible [26].

The perfectionist effect refers to how prestige seekers expect the more expensive products or services to offer greater quality [29]. At the same time, while the discussions of luxury consumptions revolve around interpersonal or social influences and other symbolic values such as materialism, the quality of the products and services is often ignored [26]. On the contrary, the higher quality of prestige or luxury products is expected to be at the minimum [70]. In the study context, one of the fundamental attributes to studying overseas is the perceived superior quality of education $[43,50]$. Although quality of education is essential in choosing overseas than local universities, measuring its role is still crucial in the prestige-seeking framework. 


\subsubsection{Hedonic Effect}

The hedonic effect refers to the tendency for an individual to prefer products that offer predominantly emotional benefits rather than functional utilities [64,71]. Products such as arts, music, or collectibles tend to be classified as hedonic products because people purchase them primarily for pleasure [29]. Premium-priced luxury goods and services are often thought to be purchased for their added emotional values [26]. Considering that attending an overseas university costs more than studying locally for Uzbek students in Korea, those who only look for higher education may not justify the price premium. Thus, it is assumed a certain level of hedonism is present that motivates them to study abroad.

Furthermore, previous studies have found that personal influence or private selfconsciousness can be influenced by social forces [72-75]. In other words, an individual's personal motivation is often shaped by the external environments [61,73,75-77]. Evidence from previous studies includes how expectations from parents and how the social image of successful people ultimately influence an individual to pursue education or lifestyle activities $[12,16,22,78]$. In the present research, the three interpersonal constructs (Veblen, snob, and bandwagon) were assumed to impact the two personal motivation constructs (hedonism and perfectionism). Accordingly, the following hypotheses were developed.

Hypothesis 1a,b. Veblen effect has a positive impact on private self-consciousness (hedonic and perfectionist effects).

Hypothesis 2a-f. Snob effect (creative choice, unpopular choice, and avoidance of similarity) has a positive impact on private self-consciousness (hedonic and perfectionist).

Hypothesis 3a-d. Bandwagon effect (normative and informative influences) has a positive impact on private self-consciousness (hedonic and perfectionist).

\subsection{Satisfaction}

Student satisfaction is one of the primary factors in the vision of universities [32]. The holistic construct of satisfaction encompasses not just a simple positive evaluation of the students but also the results of their prior expectations and perceived quality [33]. Given that students' experience at a university entails the process of being under pressure to learn and be evaluated, satisfied students usually refer to those that feel the amount of learning and personal growth exceeded the challenge and pressure [79]. In addition, the holistic experience as a student is also comprised of experiences both inside and outside of the classroom [31]. Furthermore, international students tend to also consider their experiences living in the host country where the environment is beyond the control of the university $[40,47,80]$. Therefore, the university's ability to satisfy international students is difficult to achieve $[81,82]$. Given that prior expectation is a key component of satisfaction, empirical evidence supporting the influence of personal motivation on satisfaction is abundant $[32,36,40,82]$. Accordingly, hypotheses 4 and 5 were proposed. Additionally, the illustration of the study variables and the proposed relationships is included in Figure 1.

Hypothesis 4. Perfectionist effect has a positive impact on satisfaction.

Hypothesis 5. Hedonic effect has a positive impact on satisfaction. 


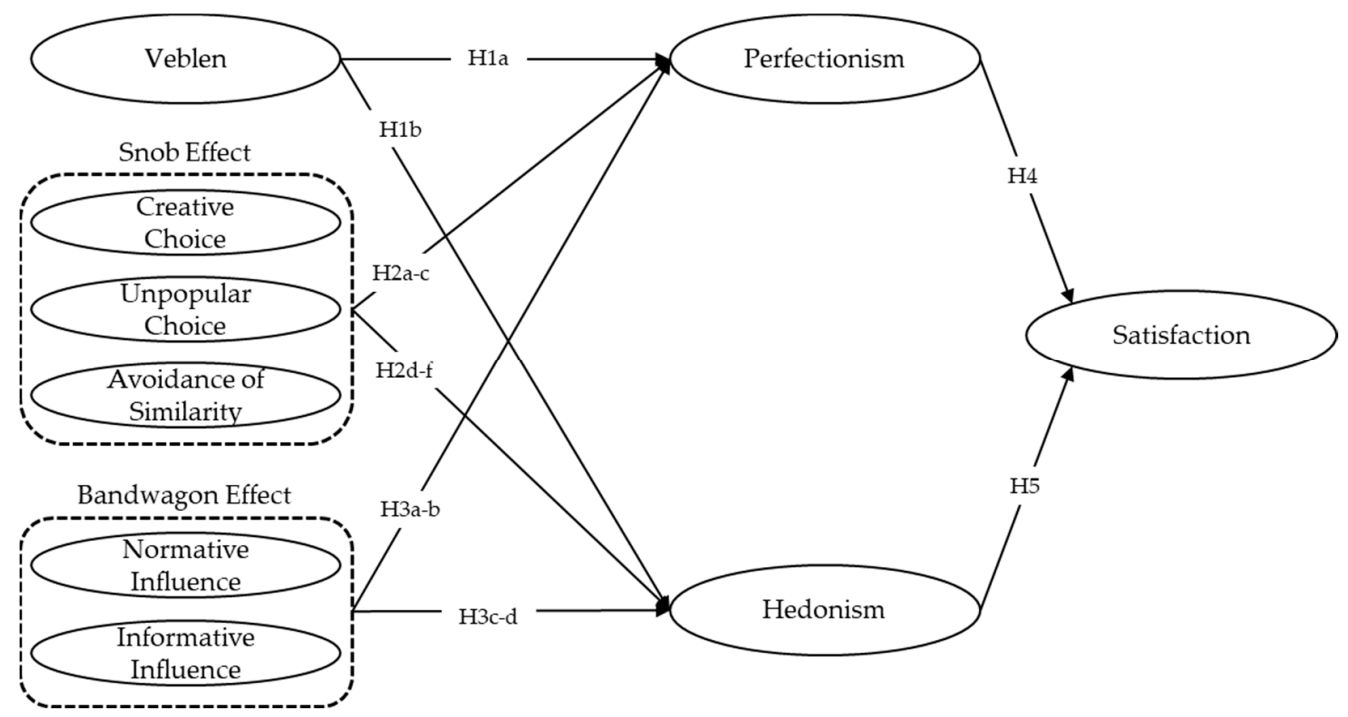

Figure 1. Proposed conceptual model.

\section{Methods}

\subsection{Measurement Items and Survey Development}

The measurement items used in the survey were adapted from previous related studies. The items used to measure the Veblen effect consisted of five items [83]. The snob effect construct consisted of three further sub-dimensions. They were creative choice, unpopular choice, and avoidance of similarity. All three dimensions were measured with four items each [60]. The bandwagon effect also consisted of two sub-dimensions, namely normative and informative. They were measured using eight and four items, respectively [66]. Then, the hedonic effect's measurement consisted of seven items [84]. The perfectionist effect was measured using four items [56]. Lastly, satisfaction was measured using five items [85]. The list of all measurement items used can be seen in Appendix A. All the measurement items used a 5-point Likert-type scale from (1) strongly disagree to (5) strongly agree.

The survey also included nine demographic questions. A short cover letter was also included at the beginning of the survey to inform the participants about the research and ensure their anonymity of participation. The final version of the survey was subjected to pre-testing by ten senior academics and professional international student agents for the comprehensiveness of the survey. The feedback and comments received from the pre-tests were only on minor language errors and formatting. Thus, a minimal amendment was made before finalizing the survey.

\subsection{Uzbek Students in Korea}

Korea started its effort to attract more international students in the early 2000s with three government campaigns. The three campaigns aimed to attract foreign institutions to invest and open institutions in Korea, highly qualified faculty, and researchers from overseas, and international students [2,3]. These policies were accredited in the growth of international students enrolling in Korea, which reached its peak of 160,165 students in 2019 before the decline due to the COVID-19 pandemic [10,80]. The majority of international students came from the following five countries in 2019: China $(69,287)$, Vietnam $(37,418)$, Mongolia (7375), Uzbekistan (7426), and Japan (4359). Interestingly, in 2020, Uzbek students increased to 9044 and is now the third-largest nationality of international students in Korea [10]. Given the distance of Uzbekistan to Korea and historical, cultural, religious, and language differences between the two countries [86-88], the prominent presence of Uzbek students in Korea is surprising. 


\subsection{Sampling and Data Collection}

The target research population of this study was international students coming from the Central Asia region. The image of Korea as a destination to study abroad is generally homogeneous among the people in the region. Additionally, the economic background, culture, and social structure are similar among the countries of Central Asia. Thus, the chosen research population should be able to provide a homogeneous evaluation of the survey, which would ultimately help increase the study's internal validity. The study implemented a nonprobability convenience sampling method to recruit research participants. The data collection was conducted online by distributing the online version of the survey on relevant social media platform groups containing international students who were either currently studying or had already completed their programs in Korea. A total of 150 completed surveys were received during the data collection period between April and June 2021.

\subsection{Data Screening}

The raw data were subjected to data screening before proceeding to the analysis stage. IBM SPSS version 23 was used to process the data. This study followed the recommendation to remove any survey with more than $10 \%$ of missing values and that some missing data should be replaced [89]. However, no cases contained any missing data. Thus, no cases were removed, and no missing values were replaced. Next, evidence of unengaged response was examined by calculating the standard deviation for each case. Any cases that produced a standard deviation less than 0.5 would be thoroughly checked for evidence of non-engagement [26]. A total of three cases were removed due to the suspicion of non-engagement. Furthermore, skewness and kurtosis scores were calculated to test for data normality and to help detect any potential outliers. All the skewness and kurtosis scores were within the recommended thresholds of the absolute value of 3 [89]. Specifically, the skewness scores ranged from -1.550 to 0.121 , and Kurtosis scores ranged from -1.509 to 2.199 . The remaining 147 cases were retained for further analysis.

\subsection{Sample Profiles}

All the respondents were either current students or former students in Korea as international students. Their age ranged between 18 and 40 years old. Most (80\%) of the respondents reported being between 21 and 30 years old. The majority of students were male $(76.2 \%)$. Over $70 \%$ of the respondents were enrolling or enrolled in a program at the undergraduate level. The hospitality and tourism management major accounted for $28.6 \%$, followed by business administration at $25.2 \%$, and computer science at $16.3 \%$. Almost all respondents came from Uzbekistan, which accounted for $95.9 \%$ of the total samples, while the rest came from Kazakhstan, Russia, and Tajikistan. The full summary of the sample profiles can be seen in Table 1 .

Table 1. Sample profiles.

\begin{tabular}{cccc}
\hline Variables & Category & Distribution & Valid Percentage \\
\hline \multirow{3}{*}{ Age (years old) } & Below 20 & 21 & 14.3 \\
& $20-30$ & 119 & 81.0 \\
Gender & $31-40$ & 7 & 4.8 \\
& Male & 112 & 76.2 \\
Study Program & Female & 35 & 23.8 \\
& Language Program & 2 & 1.4 \\
& Undergraduate Degree & 104 & 70.7 \\
& Graduate Degree & 41 & 27.9 \\
& Hospitality and Tourism & 42 & 28.6 \\
Major & Business Administration & 37 & 25.2 \\
& Computer Science & 24 & 16.3 \\
& MBA & 12 & 8.2 \\
& Others & 32 & 21.8 \\
\hline
\end{tabular}


Table 1. Cont.

\begin{tabular}{cccc}
\hline Variables & Category & Distribution & Valid Percentage \\
\hline \multirow{4}{*}{ Nationality } & Uzbekistan & 141 & 95.9 \\
& Kazakhstan & 3 & 2.0 \\
& Russia & 2 & 1.4 \\
& Tajikistan & 1 & 0.7 \\
\hline
\end{tabular}

\section{Results}

\subsection{Factor Analysis}

Two sets of factor analyses were performed on the items of the snob effect and the bandwagon effect. This process allowed for a thorough test for convergence and discriminant validity of the items as well as the ability to reduce irrelevant dimensions and items [90]. Maximum likelihood extraction with Promax rotation was used to extract the factors. Among the items measuring the snob effect construct, two factors with eigenvalues greater than 1 were extracted. All items must produce a factor loading score greater than 0.5 for them to be retained. The results yielded two factors instead of the proposed three. The Kaiser-Meyer-Olkin (KMO) measurement of the sampling adequacy score was 0.760, which is higher than the recommended 0.60 requirements [91]. Bartlett's test of sphericity level was at the $p=<0.001$ significance level. Communality scores were all above the minimum threshold of 0.40 [92]. The total variance explained score was $65.161 \%$, thus, higher than the required 50\% [89]. Factor 1, creative choice, retained all four original items. This factor was explained by $40.468 \%$ of the variance. Factor 2, avoidance of similarity, retained three of the original four. The factor was explained by $24.693 \%$ of the variance. Reliability was also satisfactory. The Cronbach's alpha scores were 0.874 to 0.867 . Both were greater than the minimum threshold of 0.70 [91]. The results also imply all four items of the unpopular choice dimensions were removed. A summary of the factor analysis of the snob effect dimensions is presented in Table 2.

Table 2. Summary of the snob effect's factor analysis results.

\begin{tabular}{|c|c|c|c|c|}
\hline Factors & $\begin{array}{l}\text { Factor } \\
\text { Loading }\end{array}$ & $\begin{array}{l}\text { Eigen- } \\
\text { Values }\end{array}$ & $\begin{array}{l}\text { Variance } \\
\text { Explained }\end{array}$ & $\begin{array}{c}\text { Cronbach's } \\
\text { Alpha }\end{array}$ \\
\hline Factor 1: Creative choice & & 3.229 & $40.468 \%$ & 0.874 \\
\hline $\begin{array}{l}\text { I often learn new skills so that I can } \\
\text { create a personal image that can be } \\
\text { difficult to duplicate. }\end{array}$ & 0.855 & & & \\
\hline $\begin{array}{l}\text { I try to find different and unique skills to } \\
\text { learn because I enjoy being original } \\
\text { I seek to develop my personal }\end{array}$ & 0.798 & & & \\
\hline $\begin{array}{l}\text { uniqueness by studying something } \\
\text { unique and different than my home }\end{array}$ & 0.767 & & & \\
\hline $\begin{array}{l}\text { Choosing something to learn that is } \\
\text { interesting and unusual assists me in } \\
\text { establishing a distinctive image }\end{array}$ & 0.745 & & & \\
\hline Factor 2: Avoidance of similarity & & 2.011 & $24.693 \%$ & 0.867 \\
\hline $\begin{array}{l}\text { I try to avoid studying at places that I } \\
\text { know are attended by the } \\
\text { general population }\end{array}$ & 0.879 & & & \\
\hline $\begin{array}{l}\text { As a rule, I dislike places to study that } \\
\text { are attended by the general population. } \\
\text { The more common the places to study } \\
\text { are among the general population, the } \\
\text { less I am interested in attending. }\end{array}$ & 0.737 & & & \\
\hline Total & & & $65.161 \%$ & \\
\hline
\end{tabular}


The 12 items adopted to measure the bandwagon effect were also subjected to factor analysis with identical settings and recommended thresholds as the snob effect. The KMO score was 0.874 , and Bartlett's test of sphericity level score was significant at a $p=<0.001$ level. Consistent with the proposed dimensions, two factors were extracted. They were explained by $71.989 \%$ of the total variance. Factor 1 , normative, was explained by $60.84 \%$ of the variance. Four items from the original eight were retained. Factor 2, informative, is comprised of three items. Hence, one item was discarded. The factor was explained by $11.15 \%$ of the variance. The Cronbach's alpha scores were 0.933 and 0.843 , respectively. A summary of the bandwagon's factor analysis results is shown in Table 3.

Table 3. Summary of the bandwagon effect's factor analysis results.

\begin{tabular}{|c|c|c|c|c|}
\hline Factors & $\begin{array}{l}\text { Factor } \\
\text { Loading }\end{array}$ & Eigen-Values & $\begin{array}{c}\text { Variance } \\
\text { Explained }\end{array}$ & $\begin{array}{c}\text { Cronbach's } \\
\text { Alpha }\end{array}$ \\
\hline Factor 1: Normative & & 4.525 & $60.837 \%$ & 0.933 \\
\hline $\begin{array}{l}\text { I do not choose places to study until I } \\
\text { am sure people in my social group } \\
\text { approve of them }\end{array}$ & 0.918 & & & \\
\hline $\begin{array}{c}\text { It is important that people in my } \\
\text { social group like a place } \\
\text { where I study. }\end{array}$ & 0.854 & & & \\
\hline $\begin{array}{l}\text { Before selecting to study abroad, I } \\
\text { like to choose places that people in } \\
\text { my social group will approve of. }\end{array}$ & 0.851 & & & \\
\hline $\begin{array}{l}\text { I decide to study where people I } \\
\text { know expect me to study }\end{array}$ & 0.828 & & & \\
\hline Factor 2: Informative & & 1.071 & $11.151 \%$ & 0.843 \\
\hline $\begin{array}{l}\text { If I have little information about } \\
\text { where to study, I ask people I know } \\
\text { about the study place }\end{array}$ & 0.957 & & & \\
\hline $\begin{array}{l}\text { I often discuss with others to help to } \\
\text { choose the best places to study. }\end{array}$ & 0.709 & & & \\
\hline $\begin{array}{l}\text { I frequently gather information from } \\
\text { friends or family about where to } \\
\text { study before I decide }\end{array}$ & 0.682 & & & \\
\hline Total & & & $71.989 \%$ & \\
\hline
\end{tabular}

\subsection{Confirmatory Factor Analysis (CFA)}

The analysis followed Anderson and Gerbing's (1988) two-step approach to structural equation modeling (SEM) [93]. The first step, confirmatory factor analysis (CFA), focused on the measurement model to establish model fit, convergence validity, discriminant validity, and reliability. Maximum likelihood extraction and Promax rotation were used for this analysis. The measurement model produced excellent model fit results $\left(x^{2}=675.529\right.$, $d f=405, p<0.001, x^{2} / d f=1.668$, RMSEA $=0.68$, CFI $=0.919$, IFI $\left.=0.921\right)$. All the constructs produced composite reliability (CR) scores between 0.814 and 0.954 , higher than the minimum threshold of 0.70 [91]. The average variance extracted (AVE) scores generated by all the constructs were also higher than the required 0.5 thresholds [91]. Furthermore, no discriminant validity concern was identified. The correlations between all variable pairs were not higher than the squared root of the AVE. Accordingly, the analysis should progress to hypotheses testing at the structural model level. A summary of the CFA results can be seen in Table 4. 
Table 4. Summary of confirmatory factor analysis results.

\begin{tabular}{ccccccccc}
\hline & $\mathbf{H d}$ & $\mathbf{V b}$ & $\mathbf{C r}$ & $\mathbf{A v}$ & Nor & Inf & Per & Sat \\
\hline Hd & $\mathbf{0 . 7 8 1} \mathbf{a}^{\mathrm{a}}$ & & & & & & & \\
$\mathrm{Vb}$ & $0.463^{\mathrm{b}}$ & $\mathbf{0 . 7 6 9}$ & & & & & & \\
$\mathrm{Cr}$ & 0.591 & 0.449 & $\mathbf{0 . 7 9 0}$ & & & & & \\
Av & 0.036 & 0.369 & 0.230 & $\mathbf{0 . 8 2 4}$ & & & & \\
Nor & -0.014 & 0.396 & -0.083 & 0.538 & $\mathbf{0 . 8 7 8}$ & & & \\
Inf & 0.254 & 0.531 & 0.112 & 0.467 & 0.684 & $\mathbf{0 . 8 0 4}$ & & \\
Per & 0.764 & 0.506 & 0.493 & 0.054 & 0.059 & 0.321 & $\mathbf{0 . 7 7 2}$ & \\
Sat & 0.537 & 0.488 & 0.391 & 0.121 & 0.286 & 0.327 & 0.359 & $\mathbf{0 . 8 9 7}$ \\
CR & 0.887 & 0.852 & 0.869 & 0.863 & 0.931 & 0.845 & 0.814 & 0.954 \\
AVE & 0.611 & 0.592 & 0.624 & 0.679 & 0.772 & 0.647 & 0.595 & 0.805 \\
\hline
\end{tabular}

Note 1. $\mathrm{Hd}=$ Hedonic, $\mathrm{VB}=$ Veblen, $\mathrm{Cr}=$ Creative, $\mathrm{Av}=$ Avoidance, Nor = Normative, $\mathrm{Inf}=$ Informative, Per $=$ Perfectionist, Sat $=$ Satisfaction. ${ }^{a}=$ Square root of AVEs is along the diagonal. ${ }^{b}=$ Correlations.

\subsection{Structural Equation Modeling}

The structural model was found to have adequate model fit statistics $\left(\mathrm{x}^{2}=731.687\right.$, $d f=411, \mathrm{x}^{2} / d f=1.780, \mathrm{RMSEA}=0.073, \mathrm{CFI}=0.904, \mathrm{IFI}=0.906, \mathrm{TLI}=0.892, \mathrm{NFI}=0.808$, PGFI $=0.633$ ). The final construct, satisfaction, was explained by $31.5 \%$ of the variance. While the hedonic construct was explained by $54.1 \%$, the highest in the study model. The total impact on satisfaction was also largest by the hedonic construct at $98 \%$. Creative choice produced the second largest total impact on satisfaction at $33.2 \%$. The results of hypothesis testing show all proposed relationships were significant except three. Hypotheses $3 \mathrm{a}$ (normative $\rightarrow$ perfectionist, $\beta=0.089$ ), 3c (normative $\rightarrow$ hedonic, $\beta=0.061$ ) and 4 (perfectionist $\rightarrow$ satisfaction, $\beta=0.122$ ) were not statistically significant. Table 5 summarizes the SEM results.

Table 5. Summary of structural equation modeling results.

\begin{tabular}{|c|c|c|c|c|}
\hline \multicolumn{3}{|c|}{ Hypotheses } & \multirow{2}{*}{$\begin{array}{c}\begin{array}{c}\text { Standardized } \\
\text { Estimate }\end{array} \\
0.112 *\end{array}$} & \multirow{2}{*}{$\begin{array}{c}\boldsymbol{t} \text {-Value } \\
2.506\end{array}$} \\
\hline H1a: Veblen & $\rightarrow$ & Perfectionist & & \\
\hline H1b: Veblen & $\rightarrow$ & Hedonic & 0.077 * & 2.235 \\
\hline H2a: Creative choice & $\rightarrow$ & Perfectionist & $0.093^{* * *}$ & 3.908 \\
\hline H2b: Avoidance of similarity & $\rightarrow$ & Perfectionist & $0.085^{*}$ & -2.572 \\
\hline H2c: Creative choice & $\rightarrow$ & Hedonic & 0.069 * & 5.036 \\
\hline H2d: Avoidance of similarity & $\rightarrow$ & Perfectionist & $0.085 *$ & -2.572 \\
\hline H3a: Normative & $\rightarrow$ & Perfectionist & 0.089 & -1.140 \\
\hline H3b: Informative & $\rightarrow$ & Perfectionist & $0.114^{* *}$ & 2.888 \\
\hline H3c: Normative & $\rightarrow$ & Hedonic & 0.061 & -1.022 \\
\hline H3d: Informative & $\rightarrow$ & Hedonic & $0.079 * *$ & 2.630 \\
\hline H4: Perfectionist & $\rightarrow$ & Satisfaction & 0.122 & -0.244 \\
\hline H5: Hedonic & $\rightarrow$ & Satisfaction & $0.180^{* * *}$ & 5.457 \\
\hline
\end{tabular}

\subsection{Indirect-Impact Assessment}

This research also examined the indirect effect between the independent and dependent variables to help to further establish the mediating roles among the mediators. The indirect impact assessment was conducted using the bootstrap method with 2000 experiments at a 95-confidence level. Among the five independent variables, only the indirect effect from creative choice to satisfaction was significant. Hence, both mediators fully mediated the independent and dependent variables. The summary of the indirect-impact assessment is included in Table 6. The proposed conceptual model with SEM results can also be seen in Figure 2. 
Table 6. Indirect-impact assessment results.

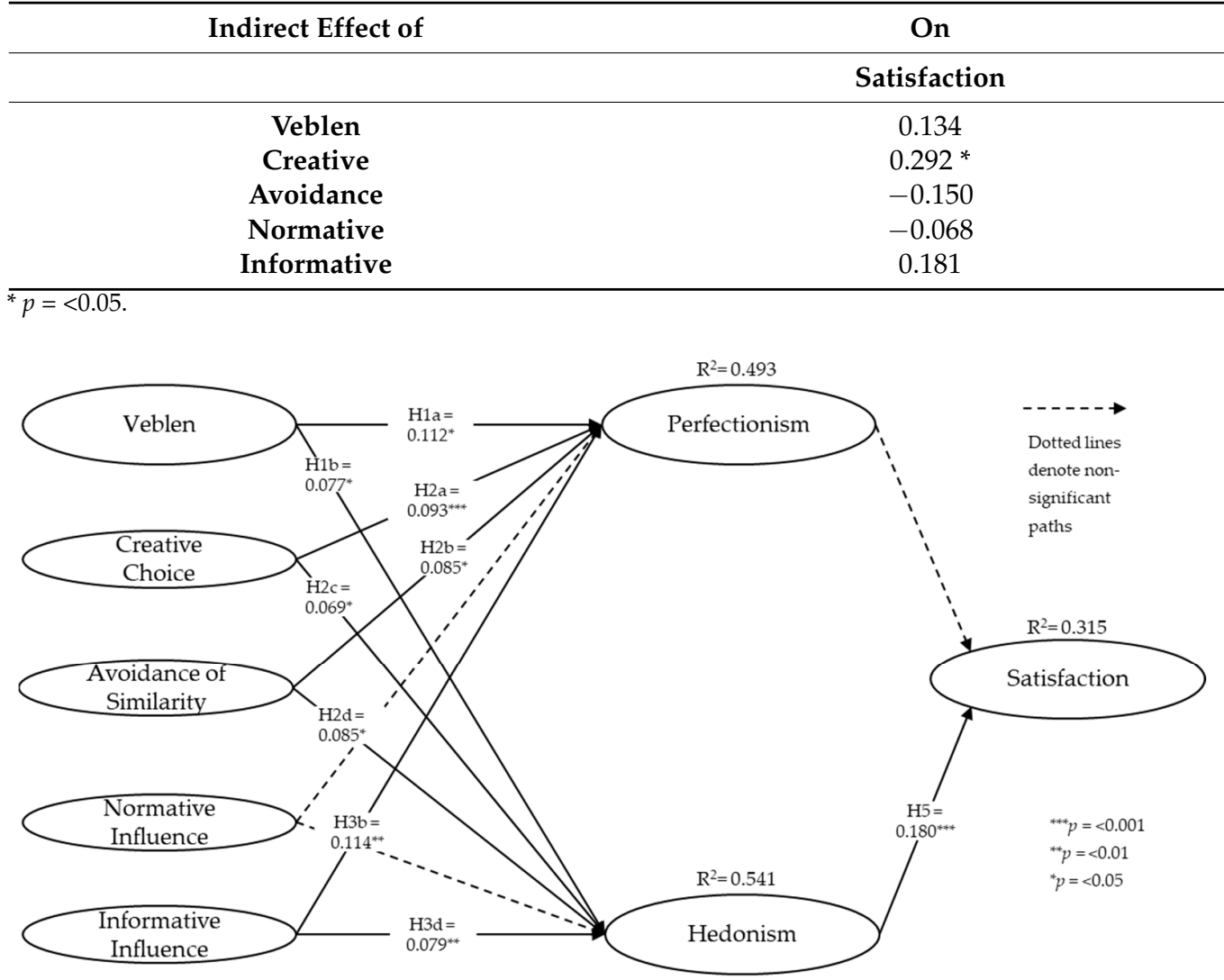

Figure 2. Proposed conceptual model and SEM results.

\section{Discussion}

\subsection{General Discussion}

The first set of analyses yielded insightful results. Part of the snob effect, namely the unpopular choice dimension, was excluded due to low loadings. This implies that higher education decisions are not driven by the urge to choose unpopular choices among the study samples to stand out from the common herd. Given the importance of education for a career prospect, recognition and image of the degree should play a crucial role among recruiters. Hence, degrees that are not recognized by the general public may be perceived as a disadvantage. The finding is consistent with previous research that people tend to follow rankings, and the higher the ranking, the more applications institutions receive $[34,36,38,42]$. At the same time, the samples still exhibited motivation to choose a study destination that is unique when compared to the known choices. Kazakhstan and Russia have traditionally been the usual choices for Uzbek students. However, Korea presents a creative choice and helps the students to avoid similarity with degree holders of the usual destinations. Thus, degrees from Korea are still perceived as prestigious among Uzbek students while also offering uniqueness for the recruiters.

In addition to uniqueness, the motivation to be part of the prestige group was also evident among the research samples. Both normative and informative influences converged strongly. The results imply that approval among the reference group in terms of education is prevalent. At the same time, the students valued consultations and recommendations from people with knowledge and experience, such as education agents or seniors. Given that previous studies found how agent recommendations influence final decisions, the findings of this present study are consistent with the empirical evidence [16,47]. However, normative influence did not consistently predict any of the personal motivations. The unexpected results might be due to that Korea is still considered an emerging destination for education. The reference groups among the samples may have conflicting approvals to 
the sample's internal preferences. Previous research has also found that popular culture such as music and other mass media are the main driving force in increasing Korea's image among the young people abroad $[78,86,88]$. Thus, such influence may not be the usual attribute of a destination for education.

Furthermore, the perfectionism construct did not significantly impact satisfaction, while hedonism provided a strong impact. In addition, the variance strongly explained both of the personal motivations, suggesting they were equally essential motives to choose Korea. The findings can be interpreted in two ways. The first is that the samples did not find the quality of education to be an essential indicator of their satisfaction level. Alternatively, the samples may feel that Korea's other attributes contributed to the overall satisfaction level than just the education quality. Note that the reported satisfaction was positive, implying that the sample was satisfied, but the contribution to satisfaction was not necessarily the educational quality.

\subsection{Implications}

The research yielded meaningful implications to various stakeholder groups. Holistically, Korea as a destination of higher education still needs to be further developed, and it would require efforts from multiple groups such as universities, agencies, and the government. Among the students and their families, the advantage of Korea is that it offers a certain level of uniqueness or novelty. The country can also provide unique learning opportunities such as the Korean language compared to the usual destinations for Uzbek students. Korea was able to leverage its entertainment industry for building awareness, but educational institutions and the ministry still need to enhance the quality of education further. Lastly, agencies would need to identify the clear strengths of Korea and avoid comparing it to other traditional destinations due to its emerging status.

Theoretically, the study contributed in several ways. First, the study validated the five dimensions of prestige-seeking consumer behavior in the overseas higher education context, which has not been done previously. The study also adopted comprehensive multi-dimensional scales instead of holistic for a thorough investigation of each prestige dimension among the five dimensions. As a result, the study was able to understand the different types of influence more specifically than it could otherwise. The conceptual framework should also provide a sound fundamental for future research to expand further and apply in more research contexts.

\subsection{Limitations}

Limitations of this study include the generalizability of the samples and the scope of the theoretical framework. The research chose to focus on a group of international students from Uzbekistan students in Korea. While the narrow focus helps boost the study's internal validity, future studies could attempt to expand it by applying the same theoretical framework to other groups of international students in Korea. Moreover, Korea is just one of the many non-English speaking countries looking to the global student market to increase their growth. Therefore, it would be of tremendous benefit to also examine the notion of prestige in other destinations. Future studies could also look at expanding the theoretical contributions by incorporating other symbolic drivers of international students. In addition, an attempt to follow up on the same samples after graduation and the benefits of international education in their career would be immensely beneficial to both the students and higher educational institutions.

Author Contributions: Conceptualization, O.J., I.M. and K.K.; methodology, O.J.; formal analysis, K.K.; data curation, I.M.; writing — original draft preparation, O.J. and I.M.; writing—review and editing, K.K. and J.-H.K.; supervision, K.K. and J.-H.K. All authors have read and agreed to the published version of the manuscript.

Funding: This research received no external funding.

Institutional Review Board Statement: Not applicable. 
Informed Consent Statement: Informed content was obtained from all subjects involved in the study.

Data Availability Statement: Not applicable.

Conflicts of Interest: The authors declare no conflict of interest.

\section{Appendix A}

Table A1. Measurement items.

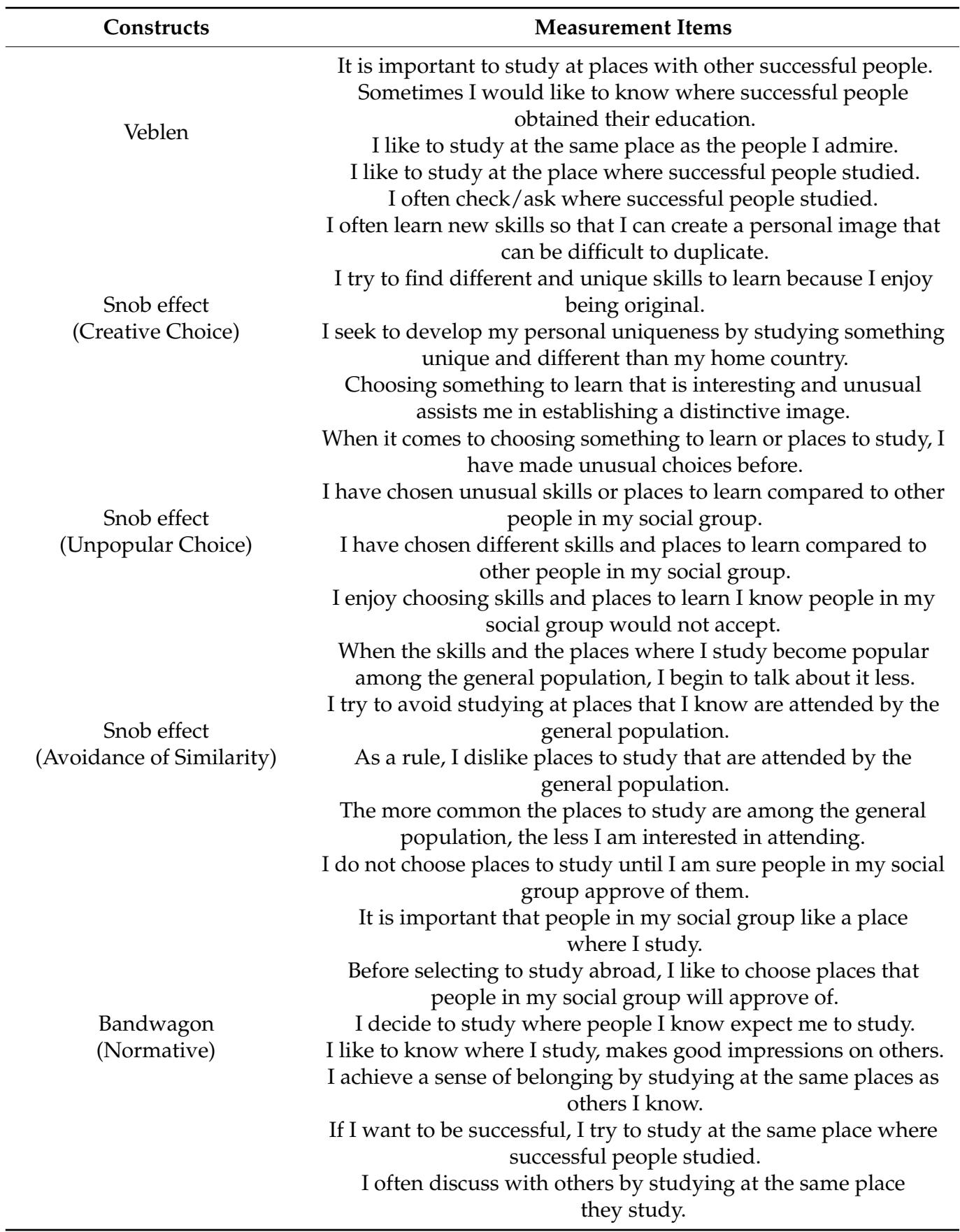


Table A1. Cont.

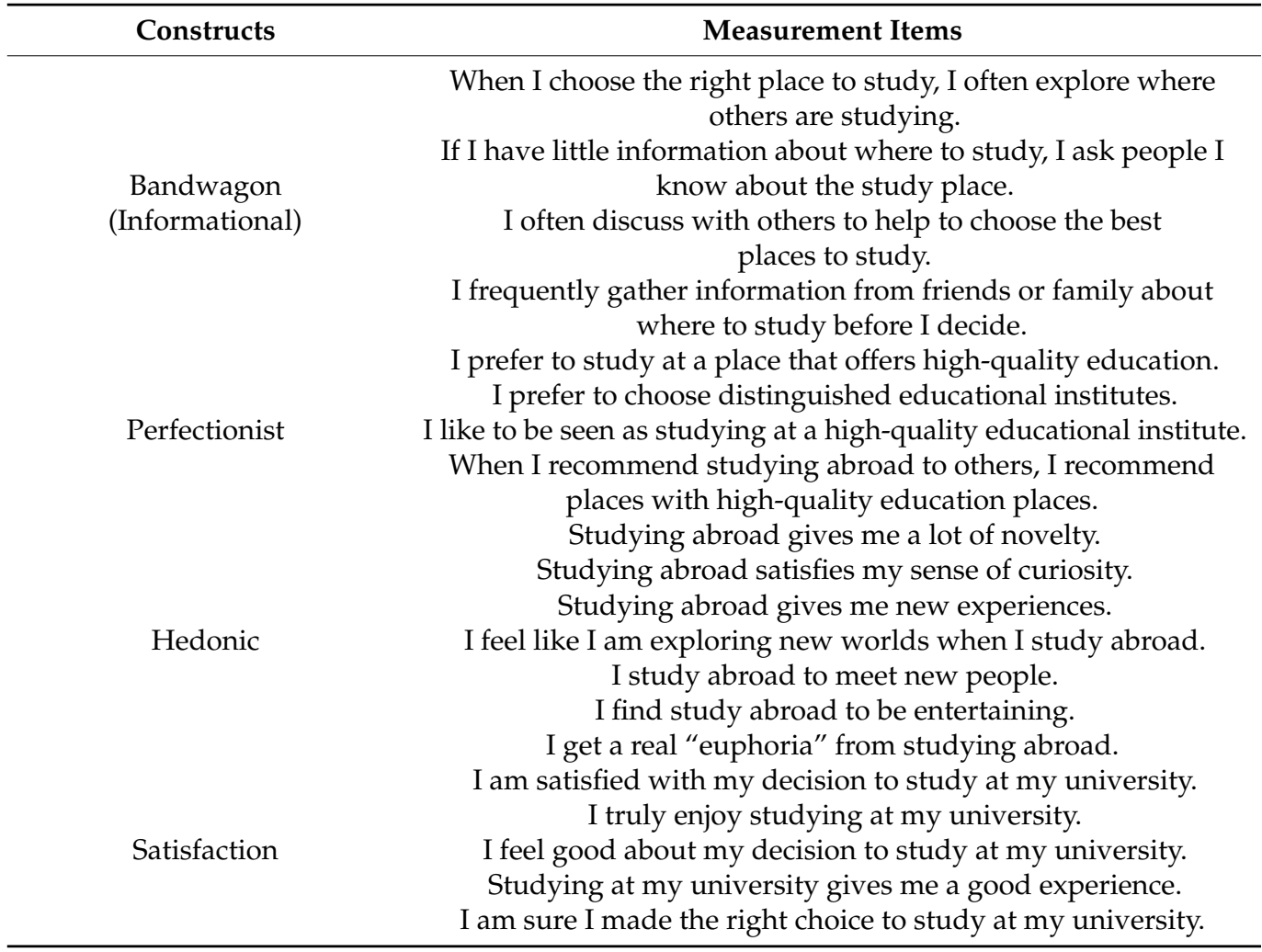

\section{References}

1. Other Policy Relevant Indicators: Inbound Internationally Mobile Students by Continent of Origin. Available online: http: / / data.uis.unesco.org/index.aspx?queryid=3804 (accessed on 24 October 2021).

2. Byun, K.; Kim, M. Shifting Patterns of the Government's Policies for the Internationalization of Korean Higher Education. J. Stud. Int. Educ. 2011, 15, 467-486. [CrossRef]

3. Shin, J.C. Higher Education Development in Korea: Western University Ideas, Confucian Tradition, and Economic Development. High. Educ. 2012, 64, 59-72. [CrossRef]

4. King, R.; Sondhi, G. International Student Migration: A Comparison of UK and Indian Students' Motivations for Studying Abroad. Glob. Soc. Educ. 2018, 16, 176-191. [CrossRef]

5. Lee, S.W. Circulating East to East: Understanding the Push-Pull Factors of Chinese Students Studying in Korea. J. Stud. Int. Educ. 2017, 21, 170-190. [CrossRef]

6. Tran, L.T.; Stafford, G.; Soejatminah, S.; Gribble, C. Building Experience, Opportunities, and the Resume: Motivations of Students Participating in Learning-Abroad Programmes through the New Colombo Plan. High. Educ. Res. Dev. 2021, 40, 416-430. [CrossRef]

7. Mazzarol, T.; Lambert, S.; Choo, S.; Nair, V.S. Australia and the Indian Postgraduate Science E Technology Market: Examining Why Indian Students Choose to Study in Countries Other than Australia; Australian Education International Department of Education, Training and Youth Affairs: Canberra, Australia, 2001; ISBN 0-642-45537-6.

8. Min-En, A.T. Travel Stimulated by International Students in Australia. Int. J. Tour. Res. 2006, 8, 451-468. [CrossRef]

9. Lee, C.-F.; King, B. International Students in Asia: Travel Behaviors and Destination Perceptions. Asia Pac. J. Tour. Res. 2016, 21, 457-476. [CrossRef]

10. Ministry of Education Korea. Available online: https://kess.kedi.re.kr/post/6672839?itemCode=04\&menuId=m_02_04_03 (accessed on 21 October 2021).

11. Griner, J.; Sobol, A. Chinese Students' Motivations for Studying Abroad. Glob. Stud. J. 2014, 7, 1-14. [CrossRef]

12. Hung, N.T.; Yen, K.L. The Role of Motivation and Career Planning in Students' Decision-Making Process for Studying Abroad: A Mixed-Methods Study. Rev. Argent. Clin. Psicol. 2020, 29, 252-265.

13. Nghia, T.L.H. Motivations for Studying Abroad and Immigration Intentions: The Case of Vietnamese Students. J. Int. Stud. 2019, 9, 758-776. [CrossRef]

14. Sánchez, C.M.; Fornerino, M.; Zhang, M. Motivations and the Intent to Study Abroad among US, French, and Chinese Students. J. Teach. Int. Bus. 2006, 18, 27-52. [CrossRef]

15. Dwyer, M.M.; Peters, C.K. The Benefits of Study Abroad. Transit. Abroad 2004, 37, 56-58. 
16. Curtis, T.; Ledgerwood, J.R. Students' Motivations, Perceived Benefits and Constraints towards Study Abroad and Other International Education Opportunities. J. Int. Educ. Bus. 2018, 11, 63-78. [CrossRef]

17. Jenny, S.E.; Chung, J.J.; Rademaker, S.M.; Almond, E.C. University students' perceived and experienced challenges and benefits to study abroad: Gender, class year, and length of experience comparisons. J. Educ. Res. 2017, 11, 457-476.

18. Skirda, T.S.; Katarovych, A. Studying Abroad and What Are the Benefits. Ph.D. Thesis, National Aviation University, Kyiv, Ukraine, 2020.

19. Trower, H.; Lehmann, W. Strategic Escapes: Negotiating Motivations of Personal Growth and Instrumental Benefits in the Decision to Study Abroad. Br. Educ. Res. J. 2017, 43, 275-289. [CrossRef]

20. Rekhter, N.; Hossler, D. Place, Prestige, Price, and Promotion: How International Students Use Social Networks to Learn about Universities Abroad. J. Soc. Media Soc. 2019, 8, 124-145.

21. Lee, S.; Nguyen, H.N.; Lee, K.-S.; Chua, B.-L.; Han, H. Price, People, Location, Culture and Reputation: Determinants of Malaysia as Study Destination by International Hospitality and Tourism Undergraduates. J. Tour. Cult. Change 2018, 16, 335-347. [CrossRef]

22. Liu, Y.; Kamnuansilpa, P.; Hirofumi, A. Factors Affecting International Students' Decisions on Destination for Studying Abroad: A Case Study in China. Front. Educ. China 2018, 13, 93-118. [CrossRef]

23. Dwivedi, A.; Nayeem, T.; Murshed, F. Brand Experience and Consumers' Willingness-to-Pay (WTP) a Price Premium: Mediating Role of Brand Credibility and Perceived Uniqueness. J. Retail. Consum. Serv. 2018, 44, 100-107. [CrossRef]

24. Hwang, J.; Han, H. Examining Strategies for Maximizing and Utilizing Brand Prestige in the Luxury Cruise Industry. Tour. Manag. 2014, 40, 244-259. [CrossRef]

25. Hwang, J.; Hyun, S.S. The Antecedents and Consequences of Brand Prestige in Luxury Restaurants. Asia Pac. J. Tour. Res. 2012, 17, 656-683. [CrossRef]

26. Kiatkawsin, K.; Han, H. What Drives Customers' Willingness to Pay Price Premiums for Luxury Gastronomic Experiences at Michelin-Starred Restaurants? Int. J. Hosp. Manag. 2019, 82, 209-219. [CrossRef]

27. Choi, Y.G.; Ok, C.; Hyun, S.S. Relationships between brand experiences, personality traits, prestige, relationship quality, and loyalty: An empirical analysis of coffeehouse brands. Int. J. Contemp. Hosp. Mang. 2017, 29, 1185-1202. [CrossRef]

28. Leibenstein, H. Bandwagon, Snob, and Veblen Effects in the Theory of Consumers' Demand. Q. J. Econ. 1950, 64, 183-207. [CrossRef]

29. Vigneron, F.; Johnson, L.W. A Review and a Conceptual Framework of Prestige-Seeking Consumer Behavior. Acad. Mark. Sci. Rev. 1999, 1, 1-5.

30. Kiatkawsin, K.; Sutherland, I. Examining Luxury Restaurant Dining Experience towards Sustainable Reputation of the Michelin Restaurant Guide. Sustainability 2020, 12, 2134. [CrossRef]

31. Han, H.; Kiatkawsin, K.; Kim, W.; Hong, J.H. Physical Classroom Environment and Student Satisfaction with Courses. Assess. Eval. High. Educ. 2018, 43, 110-125. [CrossRef]

32. Elliott, K.M. Key Determinants of Student Satisfaction. J. Coll. Stud. Retent. Res. Theory Pract. 2002, 4, 271-279. [CrossRef]

33. Browne, B.A.; Kaldenberg, D.O.; Browne, W.G.; Brown, D.J. Student as Customer: Factors Affecting Satisfaction and Assessments of Institutional Quality. J. Mark. High. Educ. 1998, 8, 1-14. [CrossRef]

34. Stuart, D. Reputational Rankings: Background and Development. New Dir. Inst. Res. 1995, 1995, 13-20. [CrossRef]

35. Tao, H.-L. Do students care more about their major or their university's reputation? Evidence from Taiwan's joint college entrance examination. J. Taiwan Norm. Univ. Educ. 2004, 49, 113-132. [CrossRef]

36. Huang, L.-L.; Chen, S.-W.; Chien, C.-L. The Effect of University Ranking on Learning Satisfaction: Social Identities and SelfIdentity as the Suppressor and Mediators: University Ranking on Learning Satisfaction. Asian J. Soc. Psychol. 2015, 18, 33-42. [CrossRef]

37. Liwinski, J. Does Studying Abroad Enhance Employability? Econ. Transit. 2019, 27, 409-423. [CrossRef]

38. Dearden, J.A.; Grewal, R.; Lilien, G.L. Strategic Manipulation of University Rankings, the Prestige Effect, and Student University Choice. J. Mark. Res. 2019, 56, 691-707. [CrossRef]

39. Davies, S.; Zarifa, D. The Stratification of Universities: Structural Inequality in Canada and the United States. Res. Soc. Stratif. Mobil. 2012, 30, 143-158. [CrossRef]

40. Ali, F.; Zhou, Y.; Hussain, K.; Nair, P.K.; Ragavan, N.A. Does Higher Education Service Quality Effect Student Satisfaction, Image and Loyalty?: A Study of International Students in Malaysian Public Universities. Qual. Assur. Educ. 2016, 24, 70-94. [CrossRef]

41. Meaux, J.B.; Saviers, B.; Traywick, L. Effects of Study Abroad on Cultural and Interprofessional Competencies. Nurse Educ. Today 2021, 103, 104928. [CrossRef]

42. Dill, D.D.; Soo, M. Academic Quality, League Tables, and Public Policy: A Cross-National Analysis of University Ranking Systems. High. Educ. 2005, 49, 495-533. [CrossRef]

43. Wu, J.C.-Y. Qualitative Study of Taiwanese Students Studying Abroad: Social Interactions, Navigating US Culture, and Experiences Learning English Language. Ph.D. Thesis, Wayne State University, Detroit, MI, USA, 2014.

44. Organisation for Economic Co-operation and Development OECD ILibrary I Education at a Glance 2011: Highlights. Available online: https://www.oecd-ilibrary.org/education/education-at-a-glance-2011_eag_highlights-2011-en (accessed on 21 October 2021).

45. Chen, P.-J.; Kerstetter, D.L. International Students' Image of Rural Pennsylvania as a Travel Destination. J. Travel Res. 1999, 37, 256-266. [CrossRef] 
46. Yolal, M.; Çetinel, F.; Uysal, M. An Examination of Festival Motivation and Perceived Benefits Relationship: Eskişehir International Festival. J. Conv. Event Tour. 2009, 10, 276-291. [CrossRef]

47. Shanka, T.; Quintal, V.; Taylor, R. Factors Influencing International Students' Choice of an Education Destination-A Correspondence Analysis. J. Mark. High. Educ. 2006, 15, 31-46. [CrossRef]

48. Pearce, P.L.; Lee, U.-I. Developing the Travel Career Approach to Tourist Motivation. J. Travel Res. 2005, 43, 226-237. [CrossRef]

49. Stofflett, R.T.; Stoddart, T. The Ability to Understand and Use Conceptual Change Pedagogy as a Function of Prior Content Learning Experience. J. Res. Sci. Teach. 1994, 31, 31-51. [CrossRef]

50. Schnusenberg, O.; De Jong, P.; Goel, L. Predicting Study Abroad Intentions Based on the Theory of Planned Behavior. Decis. Sci. J. Innov. Educ. 2012, 10, 337-361. [CrossRef]

51. Whatley, M.; Stich, A.E. From Exclusive to Inclusive: A Mixed-Methods Investigation of Study Abroad Participation and Practices. J. High. Educ. 2021, 92, 140-167. [CrossRef]

52. Dolby, N. Globalisation, Identity, and Nation: Australian and American Undergraduates Abroad. Aust. Educ. Res. 2005, 32, 101-117. [CrossRef]

53. Teichler, U.; Janson, K. The Professional Value of Temporary Study in Another European Country: Employment and Work of Former ERASMUS Students. J. Stud. Int. Educ. 2007, 11, 486-495. [CrossRef]

54. Husic, M.; Cicic, M. Luxury Consumption Factors. J. Fash. Mark. Manag. Int. J. 2009, 13, 231-245. [CrossRef]

55. Chang, E.-Y.; Lee, K.-H. Underlying Values of Prestige Seeking and Its Influence on Brand Loyalty in Clothing Consumption. Int. J. Costume Cult. 2002, 5, 24-36.

56. Veblen, T.; Mills, C.W. The Theory of the Leisure Class; CreateSpace Independent Publishing Platform: Scotts Valley, CA, USA, 2017; ISBN 1-315-13537-X.

57. Braun, O.L.; Wicklund, R.A. Psychological Antecedents of Conspicuous Consumption. J. Econ. Psychol. 1989, 10, 161-187. [CrossRef]

58. Erickson, G.M.; Johansson, J.K. The Role of Price in Multi-Attribute Product Evaluations. J. Consum. Res. 1985, 12, 195-199. [CrossRef]

59. Truong, Y.; McColl, R. Intrinsic Motivations, Self-Esteem, and Luxury Goods Consumption. J. Retail. Consum. Serv. 2011, 18, 555-561. [CrossRef]

60. Ruvio, A.; Shoham, A.; Brenčič, M.M. Consumers' Need for Uniqueness: Short-form Scale Development and Cross-cultural Validation. Int. Mark. Rev. 2008, 25, 33-53. [CrossRef]

61. Deeter-Schmelz, D.R.; Moore, J.N.; Goebel, D.J. Prestige Clothing Shopping by Consumers: A Confirmatory Assessment and Refinement of the PRECON Scale with Managerial Implications. J. Mark. Theory Pract. 2000, 8, 43-58. [CrossRef]

62. Tian, K.T.; McKenzie, K. The Long-Term Predictive Validity of the Consumers' Need for Uniqueness Scale. J. Consum. Psychol. 2001, 10, 171-193. [CrossRef]

63. Tian, K.T.; Bearden, W.O.; Hunter, G.L. Consumers' Need for Uniqueness: Scale Development and Validation. J. Consum. Res. 2001, 28, 50-66. [CrossRef]

64. Snyder, C.R.; Fromkin, H.L. Abnormality as a Positive Characteristic: The Development and Validation of a Scale Measuring Need for Uniqueness. J. Abnorm. Psychol. 1977, 86, 518. [CrossRef]

65. French, J.R.; Raven, B.; Cartwright, D. The Bases of Social Power. Class. Organ. Theory 1959, 7, 311-320.

66. Bearden, W.O.; Netemeyer, R.G.; Teel, J.E. Measurement of Consumer Susceptibility to Interpersonal Influence. J. Consum. Res. 1989, 15, 473-481. [CrossRef]

67. Bearden, W.O.; Netemeyer, R.G.; Teel, J.E. Further Validation of the Consumer Susceptibility to Interpersonal Influence Scale ACR North Am. Adv. 1990, 17, 770-776.

68. Mourali, M.; Laroche, M.; Pons, F. Individualistic Orientation and Consumer Susceptibility to Interpersonal Influence. J. Serv. Mark. 2005, 19, 164-173. [CrossRef]

69. Netemeyer, R.G.; Bearden, W.O.; Teel, J.E. Consumer Susceptibility to Interpersonal Influence and Attributional Sensitivity Psychol. Mark. 1992, 9, 379-394. [CrossRef]

70. Ryu, K.; Jang, S.S. The Effect of Environmental Perceptions on Behavioral Intentions through Emotions: The Case of Upscale Restaurants. J. Hosp. Tour. Res. 2007, 31, 56-72. [CrossRef]

71. Dichter, E. The Strategy of Desire; Routledge: Oxfordshire, UK, 2017; ISBN 978-0765808943.

72. Weber, K. The Relationship of Interest to Internal and External Motivation. Commun. Res. Rep. 2003, 20, 376-383. [CrossRef]

73. Kiatkawsin, K.; Bui, N.A.; Hrankai, R.; Jeong, K. The Moderating Roles of Sensation Seeking and Worry among Nature-Based Adventure Tourists. Int. J. Environ. Res. Public. Health 2021, 18, 2021. [CrossRef] [PubMed]

74. Plant, E.A.; Devine, P.G. Internal and External Motivation to Respond without Prejudice. J. Personal. Soc. Psychol. 1998, 75, 811. [CrossRef]

75. Kiatkawsin, K.; Sutherland, I.; Lee, S.K. Determinants of Smart Tourist Environmentally Responsible Behavior Using an Extended Norm-Activation Model. Sustainability 2020, 12, 4934. [CrossRef]

76. Bui, N.A.; Kiatkawsin, K. Examining Vietnamese Hard-Adventure Tourists' Visit Intention Using an Extended Model of GoalDirected Behavior. Sustainability 2020, 12, 1747. [CrossRef]

77. Gao, L.; Norton, M.J.T.; Zhang, Z.; To, C.K.-M. Potential niche markets for luxury fashion goods in China. J. Fash. Mark. Manag. Int. J. 2009, 13, 514-526. [CrossRef] 
78. Halim, T.M.; Kiatkawsin, K. Beauty and Celebrity: Korean Entertainment and Its Impacts on Female Indonesian Viewers' Consumption Intentions. Sustainability 2021, 13, 1405. [CrossRef]

79. Woodall, T.; Hiller, A.; Resnick, S. Making Sense of Higher Education: Students as Consumers and the Value of the University Experience. Stud. High. Educ. 2014, 39, 48-67. [CrossRef]

80. Jon, J.-E.; Lee, J.J.; Byun, K. The Emergence of a Regional Hub: Comparing International Student Choices and Experiences in South Korea. High. Educ. 2014, 67, 691-710. [CrossRef]

81. Sevier, R.A. Those Important Things: What Every College President Needs to Know About Marketing and Student Recruitment. Coll. Univ. 1996, 71, 9-16.

82. Babin, B.J.; Griffin, M. The Nature of Satisfaction: An Updated Examination and Analysis. J. Bus. Res. 1998, 41, 127-136. [CrossRef]

83. Deeter-Schmelz, D.R.; Kennedy, K.N. A global perspective on the current state of sales education in the college curriculum. J. Pers. Sell. Sales Manag. 2011, 31, 55-75. [CrossRef]

84. Hausman, A. A Multi-method Investigation of Consumer Motivations in Impulse Buying Behavior. J. Consum. Mark. 2000, 17, 403-426. [CrossRef]

85. Kim, S.; Ham, S.; Moon, H.; Chua, B.-L.; Han, H. Experience, Brand Prestige, Perceived Value (Functional, Hedonic, Social, and Financial), and Loyalty among GROCERANT Customers. Int. J. Hosp. Manag. 2019, 77, 169-177. [CrossRef]

86. Lee, O. A Study on Clothing Purchasing Behavior of the Uzbekistan Students Staying in Korea (II): Focus on the Fashion Lifestyle. J. Fash. Bus. 2019, 23, 67-80.

87. Dadabaev, T.; Soipov, J. Craving Jobs? Revisiting Labor and Educational Migration from Uzbekistan to Japan and South Korea. Acta Serica 2020, 5, 111-140.

88. Varpahovskis, E. Education as a Soft Power Tool: Korea's Approach toward Uzbekistan. In Korea's Soft Power and Public Diplomacy; Hangang Network: Seoul, Korea, 2017; pp. 101-123.

89. Hair, J.; Black, W.; Babin, B.; Anderson, R. Multivariate Data Analysis: Seven Edithion; Pearson New International Edition; Pearson Education Limited: London, UK, 2014.

90. Kiatkawsin, K.; Han, H. An Alternative Interpretation of Attitude and Extension of the Value-Attitude-Behavior Hierarchy: The Destination Attributes of Chiang Mai, Thailand. Asia Pac. J. Tour. Res. 2017, 22, 481-500. [CrossRef]

91. Bagozzi, R.P.; Yi, Y. On the Evaluation of Structural Equation Models. J. Acad. Mark. Sci. 1988, 16, 74-94. [CrossRef]

92. Nunally, J.C.; Bernstein, I. Psychometric Theory. McGraw-Hill: New York, NY, USA, 1994; ISBN 007-047849-X.

93. Anderson, J.C.; Gerbing, D.W. Structural Equation Modeling in Practice: A Review and Recommended Two-Step Approach. Psychol. Bull. 1988, 103, 411. [CrossRef] 